\title{
Bortezomib-Associated Severe Orthostatic Hypotension and Hyponatremia
}

\section{Bortezomib İlişkili Ortostatik Hipotansiyon ve Hiponatremi}

\author{
Elif Suyanı ${ }^{1}$, Zeynep Akı ${ }^{1}$, Zeynep Arzu Yeğin ${ }^{1}$, Gülsan Türköz Sucak ${ }^{1}$ \\ ${ }^{1}$ Gazi University, School of Medicine, Department of Hematology, Ankara, Turkey
}

\section{To the Editor,}

The most frequent side effects of bortezomib are fatigue, hematologic toxicity with cytopenias, and peripheral neuropathy, whereas postural hypotension and hyponatremia are less common late side effects $[1,2]$. Hyponatremia is a potentially fatal complication that has been reported in 3\%-22\% of patients treated with bortezomib, and has been attributed to direct bortezomib toxicity and syndrome of inappropriate anti-diuretic hormone secretion (SIADH) [3]. The direct toxicity of bortezomib might be dose dependent [1]; however; there is insufficient evidence to support this mode of action. We think hyponatremia in the presented patient was due to direct bortezomib toxicity, as it resolved following cessation of bortezomib and saline infusion.

A 68-year-old male with IgG kappa multiple myeloma had undergone autologous hematopoetic stem cell transplantation (ASCT). The disease progressed despite posttransplantation thalidomide maintenance. Cyclophosphamide and dexamethasone (CD) was commenced 6 months post-transplantation; however, disease progression continued and 2 years post ASCT bortezomib monotherapy was started at the dose of $1.3 \mathrm{mg} \mathrm{m}^{-2}$ on $\mathrm{d} 1,4,8$, and 11 , every 3 weeks. The first 2 courses of bortezomib were uneventful; however, on $\mathrm{d} 7$ of the third cycle the patient was admitted to hospital due to dizziness and a syncope episode. Physical examination showed severe orthostatic hypotension in the absence of compensatory tachycardia, with blood pressure of 120/80 $\mathrm{mmHg}$ in the supine posi- tion and 60/50 mmHg while standing. He was not clinically dehydrated and there were no signs of infection or edema. Laboratory investigations showed isolated hyponatremia without any other electrolyte abnormality ( $\mathrm{Na}$ : $126 \mathrm{mmol} \mathrm{L}^{-1}$; K: $3.5 \mathrm{mmol} \mathrm{L}{ }^{-1}$; Cl: $98 \mathrm{mmol} \mathrm{L}^{-1}$ ). Serum biochemistry, including the renal profile, was normal. A written consent was obtained from the patient about the treatments and use of data in his file.

Bortezomib was withdrawn and isotonic saline infusion was commenced. Sodium returned to normal without requiring fluid restriction; however, there was no improvement in orthostatic hypotension, despite normal cardiac findings. Holter electrocardiography, echocardiography, and carotid Doppler ultrasound were also normal, which excluded the possibility of cardiac etiology. Neurologic examination was suspicious for peripheral sensorial neuropathy, which was confirmed via electromyography. Pregabalin $75 \mathrm{mg}$ b.i.d. was started and the dose was increased to $150 \mathrm{mg}$ b.i.d. 7 days later The patient's clinical condition improved 2 weeks after starting pregabalin treatment, without a recurrent syncope and with decreased dizziness.

Postural hypotension occurs in $10 \%$ of patients treated with bortezomib and is associated with dehydration, concomitant anti-hypertensive treatment, and/or autonomic neuropathy [4]. The presented patient had no signs of dehydration and postural hypotension did not improve with saline infusion. Moreover, the presence of widespread peripheral neuropathy and the absence of compensatory

\section{Address for Correspondence: Elif SUYANI, M.D.}


tachycardia suggested that autonomic neuropathy was the cause of orthostatic hypotension.

As the number of myeloma patients treated with bortezomib increases, so is awareness of bortezomib-related side effects. Orthostatic hypotension associated with autonomic neuropathy and hyponatremia seems to be reversible with cessation of bortezomib and use of pregabalin. In conclusion, orthostatic hypotension and hyponatremia should be included in the differential diagnosis of treatment-related toxicity in myeloma patients treated with bortezomib.

\section{Conflicts of Interest Statement}

None of the authors of this letter have any conflicts of interest, including specific financial interests, relationships, and/or affiliations, relevant to the subject matter or materials included.

\section{References}

1. Orlowski RZ, Stinchcombe TE, Mitchell BS, Shea TC, Baldwin AS, Stahl S, Adams J, Esseltine DL, Elliott PJ, Pien CS, Guerciolini R, Anderson JK, Depcik-Smith ND, Bhagat R, Lehman MJ, Novick SC, O'Connor OA, Soignet SL. Phase I trial of the proteasome inhibitor PS-341 in patients with refractory hematologic malignancies. J Clin Oncol 2002; 20 (22): 4420-4427

2. O'Connor OA, Wright J, Moskowitz C, Muzzy J, MacGregorCortelli B, Stubblefield M, Straus D, Portlock C, Hamlin P, Choi E, Dumetrescu O, Esseltine D, Trehu E, Adams J, Schenkein D, Zelenetz AD. Phase II clinical experience with the novel proteasome inhibitor bortezomib in patients with indolent non-Hodgkin's lymphoma and mantle cell lymphoma. J Clin Oncol 2005; 23 (4): 676-684

3. Brodmann S, Gyr Klaas E, Cathomas R, Girardi V, von Moos R. Severe hyponatremia in a patient with mantle cell lymphoma treated with bortezomib: A case report and review of the literature. Onkologie 2007; 30 (12): 651-654

4. Rajkumar SV, Richardson PG, Hideshima T, Anderson KC. Proteasome inhibition as a novel therapeutic target in human cancer. J Clin Oncol 2005; 23 (3): 630-639 